Наносистели, нанолатеріали, нанотехнології Nanosistemi, Nanomateriali, Nanotehnologii 2019 , т. 17 , № 3, сc. 557-566 (c) 2019 ІМФ (Інститут металофізики ім. Г. В. Курдюмова НАН України) Надруковано в Україні. Фотокопіювання дозволено тільки відповідно до ліцензії

PACS numbers: 05.10.Ln, 05.70.Ce, 64.75.Ef, 65.40.gd, 81.30.Bx, 81.30.Fb, 82.60.Lf

\title{
Modelling of Transition Metal High-Entropy Solid Solutions
}

\author{
A. B. Melnick ${ }^{1}$, V. Ya. Beloshapka ${ }^{2}$, and V. K. Soolshenko ${ }^{1}$ \\ ${ }^{1}$ G. V. Kurdyumov Institute for Metal Physics, N.A.S. of Ukraine, \\ 36, Academician Vernadsky Blvd., \\ UA-03142 Kyiv, Ukraine \\ ${ }^{2}$ Berdyansk State Pedagogical University, \\ 4, Schmidt Str., \\ UA-71100 Berdyansk, Ukraine
}

The compositions of high-entropy alloys based on the elements $\mathrm{Ni}, \mathrm{Co}, \mathrm{Fe}$, $\mathrm{Cr}, \mathrm{Mn}, \mathrm{Ti}, \mathrm{V}, \mathrm{Cu}, \mathrm{Al}, \mathrm{Zr}$, and $\mathrm{Si}$ are evaluated with use of thermodynamic approach. Optimal compositions for alloys with minimal Gibbs energy are obtained, and influence of various factors on formation of the alloys is described. As shown, the most stable alloys are nonequiatomic. The compositions for alloys, which will be in the state of homogeneous multicomponent solid solutions, are determined.

Композиції для високоентропійних стопів на основі елементів $\mathrm{Ni}$, Co, $\mathrm{Fe}, \mathrm{Cr}, \mathrm{Mn}, \mathrm{Ti}, \mathrm{V}, \mathrm{Cu}, \mathrm{Al}, \mathrm{Zr}$, Si оцінювали з використанням термодинамічного підходу. Одержано оптимальні концентрації для стопів з мінімальною Гіббсовою енергією та описано вплив різних чинників на їх формування. Показано, що найстабільніші стопи не є еквіатомовими. Визначено склади стопів, які перебуватимуть у стані однорідних багатокомпонентних твердих розчинів.

Составы высокоэнтропийных сплавов на основе элементов $\mathrm{Ni}$, Co, $\mathrm{Fe}$, $\mathrm{Cr}, \mathrm{Mn}, \mathrm{Ti}, \mathrm{V}, \mathrm{Cu}, \mathrm{Al}, \mathrm{Zr}$, Si рассматривались с использованием термодинамического подхода. Получены оптимальные концентрации для сплавов с минимальной энергией Гиббса и описано влияние различных факторов на их формирование. Было показано, что наиболее стабильные сплавы не являются эквиатомными. Определены составы сплавов, которые будут находиться в состоянии однородных многокомпонентных твёрдых растворов.

Key words: high-entropy alloys, solid solution, Gibbs energy, transition metals.

Ключові слова: високоентропійні стопи, твердий розчин, Гіббсова енер- 
гія, перехідні метали.

Ключевые слова: высокоэнтропийные сплавы, твёрдый раствор, энергия Гиббса, переходные металлы.

(Received 27 March, 2019)

\section{INTRODUCTION}

The idea of high-entropy alloys (HEAs) was proposed by Yeh et al. in 2004 [1] and based on the concept that the high configurational entropy would stabilize the solid solution (SS) phase. HEAs are multicomponent (5 or more) bulk solid solutions, intermetallics or glasses with near equiatomic composition [1-5]. This can provide a large value of change mixing entropy $\left(\Delta S_{\text {mix }}\right)$ for the formation of homogeneous system. For regular solution,

$$
\Delta S_{\text {mix }}=-k \sum_{i=1}^{n} c_{i} \ln \left(c_{i}\right),
$$

where $c_{i}$ is the atomic fraction of $i$-th element, $k$-Boltzmann constant.

According to (1), the maximum effect of the entropy factor will be for the equiatomic case.

In recent years, high-entropy solid solutions (HESS) have attracted increasing attentions, because they exhibit special structure and unique properties. Many HEA studies are devoted to the search for single-phase SS [6, 7].

The thermodynamic properties of alloy are very important for understanding of relative stability of single-phase SS. In concordance with thermodynamics, a system will be in a stable equilibrium state, if it has the lowest Gibbs free energy. The difference between the Gibbs free energy of solid phase and liquid state is as follows:

$$
\Delta G=\Delta H-T \Delta S,
$$

where $\Delta H$ is the formation enthalpy, $T$-absolute temperature, $S-$ total entropy.

Many methods have been devised to estimate the formation enthalpies and other thermodynamic properties of alloys with a single solid-solution phase:

1) first-principles' calculations within the framework of density functional theory combined with atomistic simulation techniques like ab initio calculations, molecular dynamics simulations, and Monte Carlo methods [8-13];

2) solution thermodynamics based on extrapolation of experimental 
data as in the CALPHAD [14-16];

3) semi-empirical Miedema's model and empirical thermophysical parameters based on the Hume-Rothery rules [17].

It should be noted that first-principle calculations and atomistic simulation techniques have a high computational difficulties for multicomponent systems. The CALPHAD method needs extensive database of experimental thermodynamic functions of multicomponent alloys. Various thermophysical parameters were proposed to predict formation of single-phase solid solutions. Among them are: mixing entropy $\Delta S_{\text {mix }}$ [18], mixing enthalpy $\Delta H_{\text {mix }}$ [18], differences of atomic sizes $\delta_{r}$ [18], $\Omega=T_{m} \Delta S_{\text {mix }} /\left|\Delta H_{\text {mix }}\right|$ [19], valence-electron concentration (VEC) [20], electronegativity difference $\delta_{\chi}[21]$, the $\varphi$ parameter [22] and other. An analysis of these parameters gives possibility to conclude, whether the alloy will be in the state of solid solution. However, such an approach is semi-quantitative and do not allow to optimize the alloy composition. For estimations that are more accurate, the Miedema's method has to be adapted. Takeuchi and Inoue [23] supposed that, for multicomponent glasses, $\Delta G$ is proportional to free energy $\Delta G_{\text {mix }}$ of liquid-phases' mixing:

$$
\Delta G_{\text {mix }}=\Delta H_{\text {mix }}-T \Delta S_{\text {mix }}
$$

here, $H_{\text {mix }}$ is an enthalpy of mixing. In solid solutions, where atoms of different sizes occupy equivalent lattice positions, an additional elastic contribution $\left(\Delta H_{\mathrm{el}}\right)$ has to be taken into account:

$$
\Delta H=\Delta H_{\text {mix }}+\Delta H_{\mathrm{el}}, \Delta G=\Delta H_{\text {mix }}+\Delta H_{\mathrm{el}}-T \Delta S_{\text {mix }} \cdot
$$

Regular solution model has been adopted in order to simplify the calculation of (2) and for minimization of $\Delta G$ on element concentrations [24]. Thus, it is possible to obtain the most stable multicomponent solutions.

Since Cantor alloy [25], single-phase NiCoFeCr-based HEAs are the promising materials with high tensile ductility and fracture toughness [26]. Development of NiCoFeCr-based HEAs was continued by adding elements into equiatomic $\mathrm{NiCoFeCr}$ base for strengthening. The composition of the most stable HEA may be different from the equiatomic one because some contributions additional to entropy. To find the compositions of stable solid solutions including $\mathrm{Ni}, \mathrm{Co}, \mathrm{Fe}, \mathrm{Cr}, \mathrm{Mn}, \mathrm{Ti}, \mathrm{V}, \mathrm{Cu}, \mathrm{Al}, \mathrm{Zr}$, Si elements, we minimize Gibbs free energies of investigated systems.

\section{MODELLING}

Compositions for HEAs with minimal Gibbs free energy were ob- 
tained based on thermodynamic approach developed in the article [24], where substitutional solid solutions were considered with the regular-solution approximation. The parameters for expression (2) were determined as follow. The mixing enthalpy of multicomponent alloy consisting of $n$ elements is as follows [27]:

$$
\Delta H_{\text {mix }}=\sum_{i, j=1}^{n} c_{i \neq j} c_{j} \Omega_{i j},
$$

where $\Omega_{i j}$ is parameter characterizing the interaction between $i$-th and $j$-th elements of the regular solution; $\Omega_{i j}=4 \Delta H_{\text {mix }}^{i j} ; c_{i}$-atomic fraction of $i$-th component; $\Delta H_{\text {mix }}^{i j}$-mixing enthalpy for binary liquid equiatomic alloy. The values $\Delta H_{\text {mix }}^{i j}$ were taken from Ref. [28].

The elastic distortion energy for the solid solution $\Delta H_{\mathrm{el}}$ is:

$$
\Delta H_{\mathrm{el}}=\sum_{i=1}^{n} c_{i} B_{i} \frac{\left(V_{i}(T)-V(T)\right)^{2}}{2 V_{i}(T)}
$$

here, $V(T)$ is the average volume of atom in the alloy; $V_{i}(T)$-atomic volume and $B_{i}$-bulk modulus of $i$-th element.

$$
V_{i}(T)=V_{0 i}\left(1+\alpha_{i}\left(T-T_{0}\right)\right)^{3},
$$

$\alpha_{i}$ is linear expansion coefficient for the $i$-th component; $T_{0}=293 \mathrm{~K}$.

$$
V(T)=\sum_{i=1}^{n} c_{i} B_{i} V_{i}(T) / \sum_{i=1}^{n} c_{i} B_{i}
$$

The effective melting temperature of solid solution, $T_{m}$, was calculated as

$$
T_{m}=\sum_{i=1}^{n} c_{i} T_{m}^{i},
$$

where $T_{m}^{i}$ is melting temperature of the $i$-th element.

Then, Gibbs free-energy concentration dependence can be written as

$$
\underset{i=1 \div n}{\Delta G}\left(c_{i}\right)=\sum_{i, j=1}^{n} c_{i \neq j} c_{j} \Omega_{i j}+\sum_{i=1}^{n} c_{i} B_{i} \frac{\left(V_{i}(T)-V(T)\right)^{2}}{2 V_{i}(T)}-k T_{m} \sum_{i=1}^{n} c_{i} \ln \left(c_{i}\right) .
$$

$\Delta G$ minimization was carried out using the Monte Carlo method. The values of the constants $\alpha_{i}, V_{0 i}, B_{i}, T_{m}^{i}$ in expression (5) were taken from tables of Ref. [29]. The minima of $\Delta G$ correspond to the compositions of stable alloys. To analyse the state of alloys, a number parameters were used: $\Delta G, \Delta H_{\text {mix }}, \Delta H_{\text {el }}, \Delta S_{\text {mix }}, T_{m}$, and 
$\Omega=T_{m} \Delta S_{\text {mix }} /\left|\Delta H_{\text {mix }}\right|$,

$$
\delta=\sqrt{\sum_{i=1}^{n} c_{i}\left(1-\frac{r_{i}}{\bar{r}}\right)^{2}},
$$

where $r_{i}=\left(V_{0 i}\right)^{1 / 3}, \bar{r}=\sum_{i=1}^{n} c_{i} r_{i}$.

\section{RESULTS AND DISCUSSION}

The calculation results are summarized in tables for different element combinations (Table 1 for equiatomic alloys and Table 2 for alloys with minimal Gibbs free energy).

TABLE 1. Calculated parameters $\Delta G, \Delta H_{\text {mix }}, \Delta H_{\mathrm{el}}, \delta, \Omega, \Delta S_{\text {mix }}$, and $T_{m}$ for equiatomic alloys.

\begin{tabular}{|c|c|c|c|c|c|c|c|c|}
\hline No. & Alloys & 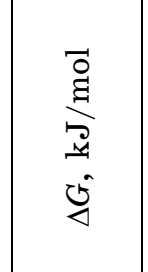 & 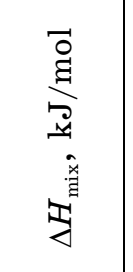 & 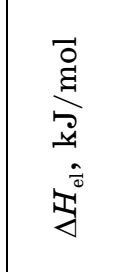 & $\begin{array}{l}0^{\circ} \\
10^{\circ}\end{array}$ & $\Omega$ & 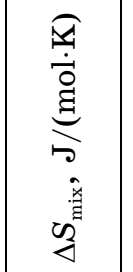 & $\hat{E}$ \\
\hline 1 & $\mathrm{NiCoFe}$ & -16.971 & -1.333 & 0.5221 & 1.068 & 12.119 & 9.135 & 1769 \\
\hline 2 & $\mathrm{NiCoCr}$ & 21.873 & -4.889 & 0.2988 & 1.373 & 3.535 & 9.135 & 1892 \\
\hline 3 & $\mathrm{CoFeCr}$ & -19.853 & -2.667 & 0.3492 & 1.134 & 6.576 & 9.135 & 1920 \\
\hline 4 & $\mathrm{NiCoFeCr}$ & -24.850 & -3.750 & 0.4755 & 1.306 & 5.753 & 11.527 & 1872 \\
\hline 5 & $\mathrm{NiCoFe}$ & -19.784 & 3.200 & 0.6889 & 1.241 & 7.398 & 13.3821 & 176 \\
\hline 6 & $\mathrm{~N}$ & -24.896 & -12.320 & 9.959 & 5.281 & 1.829 & 13.3821 & 168 \\
\hline 7 & $\mathrm{NiCc}$ & -31.258 & -26.400 & 19.695 & 7.9 & 0.930 & 13.382 & 183 \\
\hline 8 & $\mathrm{NiCoF}$ & -26.864 & -4.160 & 1.400 & 1.454 & 5.7941 & 13.382 & 1801 \\
\hline 9 & $\mathrm{CoI}$ & -27.569 & -16.320 & 13.984 & 6.1 & 1.5461 & 13.382 & 188 \\
\hline 10 & $\mathrm{NiCoFeCrZr}$ & -23.063 & -22.720 & 25.390 & 10.21 & 1.132 & 13.3821 & 192 \\
\hline 11 & $\mathrm{NiCoFeCrV}$ & -31.089 & -8.960 & 3.752 & 2.896 & 2.888 & 13.382 & 1934 \\
\hline 12 & $\mathrm{NiCoFeCrCuAl}$ & -20.823 & -4.778 & 8.233 & 4.867 & 5.081 & 14.898 & 1630 \\
\hline 13 & NiCoFeCrCuAlSi & -25.463 & -18.857 & 19.894 & 7.476 & 1.405 & 16.180 & 1638 \\
\hline 14 & $\mathrm{NiCoFeCrCuAlSiV}$ & -31.985 & -20.687 & 18.199 & 7.00 & 1.425 & 17.290 & 1706 \\
\hline 15 & NiCoFeCrCuAlMnV & -28.919 & -7.625 & 7.840 & 4.424 & 3.821 & 17.2901 & 1685 \\
\hline 16 & $\mathrm{NiCoFeCrCl}$ & -27.841 & -1.959 & 3.119 & 2.467 & 14.802 & 16.180 & 1792 \\
\hline 17 & NiCoFeCrCuAlM $n$ TiZrV & -30.050 & -18.840 & 22.387 & 8.186 & 1.783 & 19.145 & 1755 \\
\hline
\end{tabular}




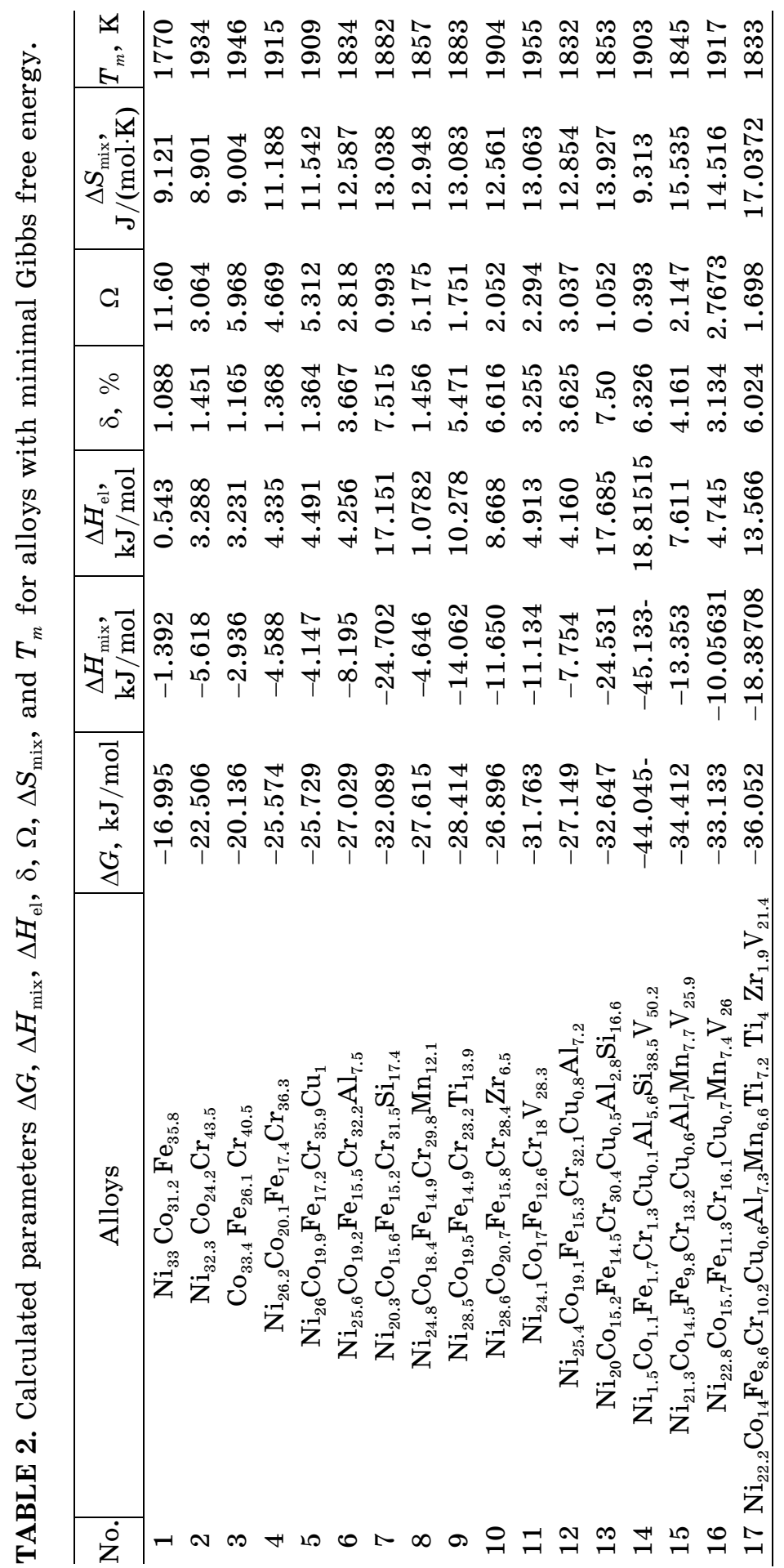


Optimized alloy compositions differ significantly from equiatomic. Gibbs free-energy-composition diagrams for ternary and quasiternary alloy systems (Figs. 1, 2) illustrate the differences of compositions.

If we consider a system consisting of 4 base elements $(\mathrm{Ni}, \mathrm{Co}, \mathrm{Fe}$, $\mathrm{Cr}$ ), we can observe the existence of a wide range of concentrations near the equiatomic point, where a single solid solution will be formed (see Fig. 1 and Tables 1, 2). CALPHAD calculations with experimental verifications [26] indicate the same result.

What elements can be added to the base composition to reduce Gibbs energy and not destroy the solid solution? Let us explore this question. If we examine equiatomic compositions (see Table 1), the additions of $\mathrm{Al}, \mathrm{Si}, \mathrm{Mn}, \mathrm{Ti}, \mathrm{V}$ to the base elements decreases the Gibbs energy, while other components increase it more $(\mathrm{Cu})$ or less (Zr). Parameters $\Delta H_{\text {mix }}, \delta, \Omega$ play a special role in formation of solid solutions. When $\delta<6 \%$ and $\Delta H_{\text {mix }}>-10 \mathrm{~kJ} / \mathrm{mol}$, solid solution is

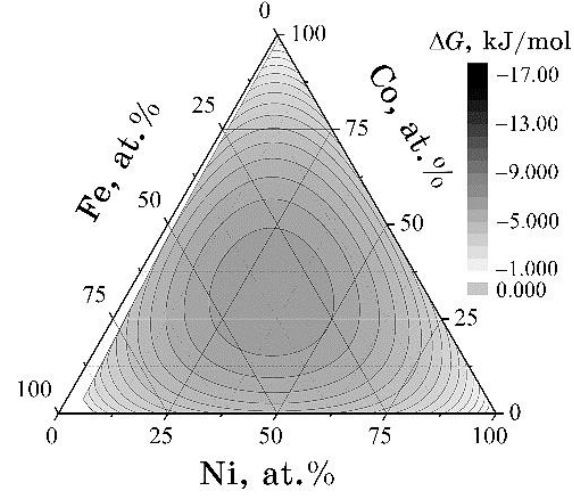

$a$

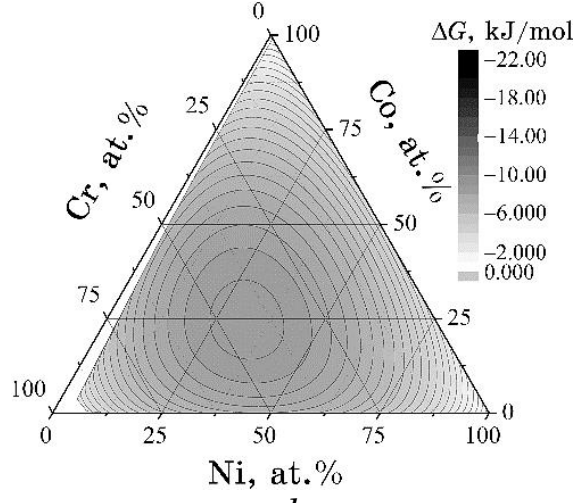

$b$

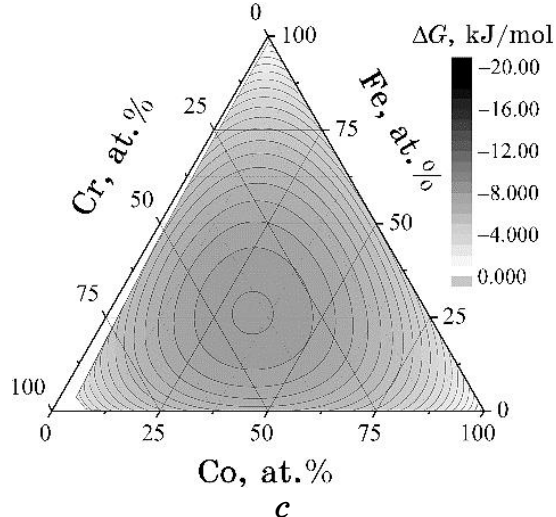

Fig. 1. The calculated Gibbs free energy of solid solutions $(\Delta G)$ for ternary $\mathrm{Ni}-\mathrm{Co}-\mathrm{Fe}(a), \mathrm{Ni}-\mathrm{Co}-\mathrm{Cr}(b), \mathrm{Co}-\mathrm{Fe}-\mathrm{Cr}(c)$ alloy systems. 

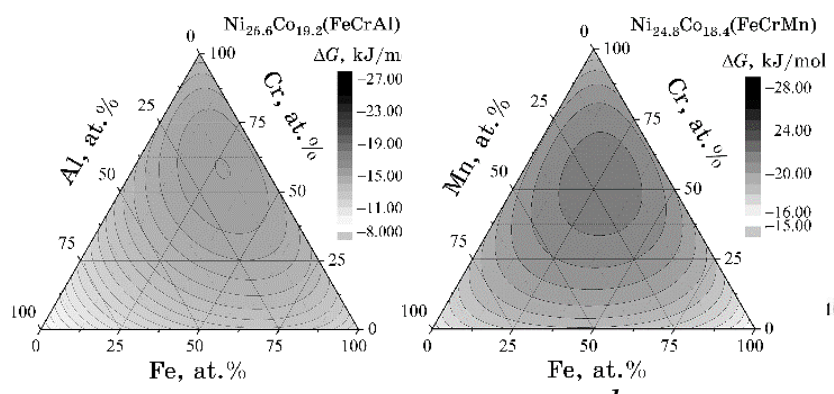

$b$

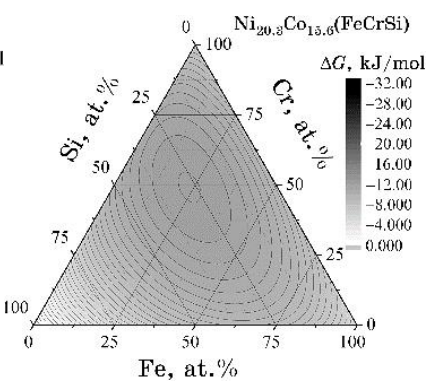

- $\quad \mathrm{Ni}_{28 . .5} \mathrm{CO}_{19.5}(\mathrm{FeCrTi})$
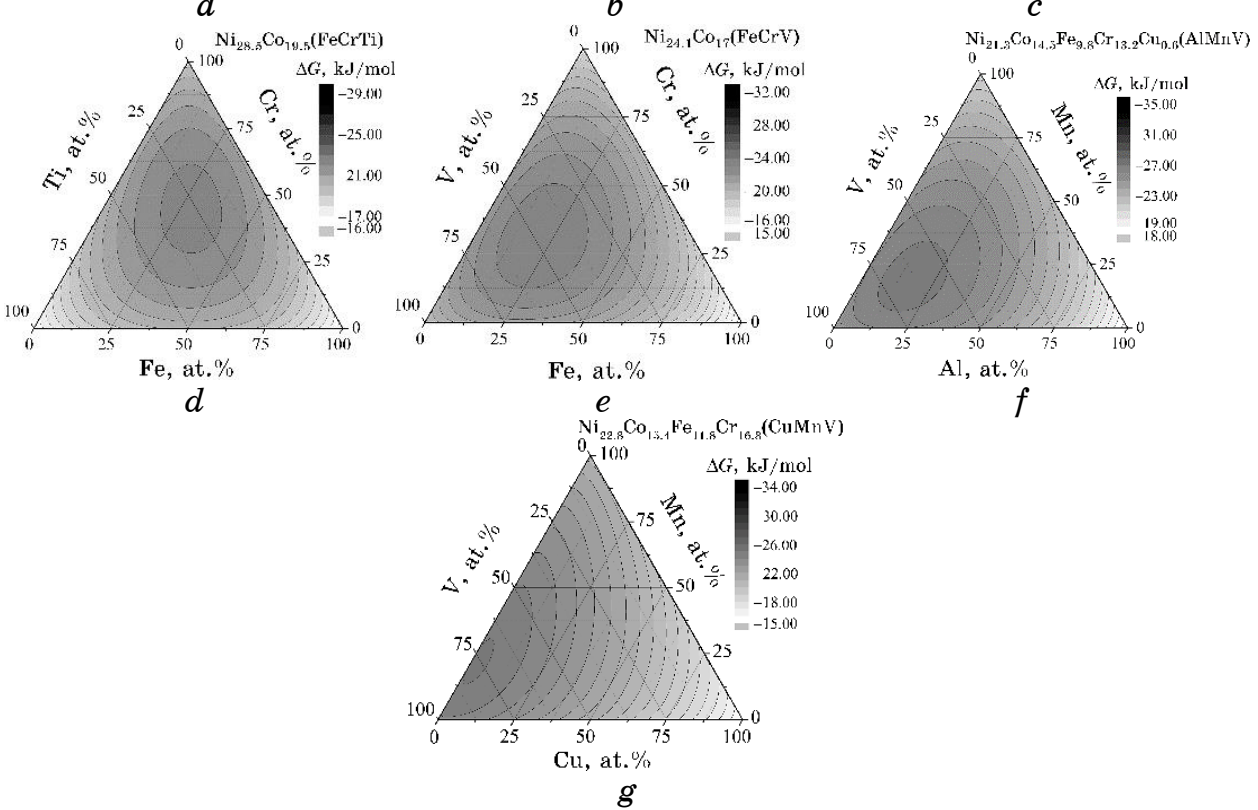

, at. $\%$

Fig. 2. The calculated Gibbs free energy of solid solutions $(\Delta G)$ for quasiternary $\mathrm{Ni}_{25.6} \mathrm{Co}_{19.2}(\mathrm{FeCrAl})(a), \mathrm{Ni}_{24.8} \mathrm{Co}_{18.4}(\mathrm{FeCrMn})(b), \mathrm{Ni}_{20.3} \mathrm{Co}_{15.6}(\mathrm{FeCrSi})$ (c), $\mathrm{Ni}_{28.5} \mathrm{Co}_{19.5}(\mathrm{FeCrTi})(d), \mathrm{Ni}_{24.1} \mathrm{Co}_{17}(\mathrm{FeCrV})(e), \mathrm{Ni}_{21.3} \mathrm{Co}_{14.5} \mathrm{Fe}_{9.8} \mathrm{Cr}_{13.2} \mathrm{Cu}_{0.6}$ $(\mathrm{AlMnV})(f), \mathrm{Ni}_{22.8} \mathrm{Co}_{15.4} \mathrm{Fe}_{11.8} \mathrm{Cr}_{16.8}(\mathrm{CuMnV})(g)$ alloy systems.

crystallized [30].

According to Ref. [31], relations $\Omega \geq 1.1$ and $\delta \leq 6.6 \%$ should be considered as criteria for forming solid-solution phase. Thus, it can be concluded that the $(\mathrm{NiCoFeCr}, \mathrm{NiCoFeCrCu}$, NiCoFeCrAl, NiCoFeCrMn, NiCoFeCrV, NiCoFeCrCuAl, NiCoFeCrCuMnV, NiCo$\mathrm{FeCrCuAlMnV)} \mathrm{equiatomic} \mathrm{alloys} \mathrm{will} \mathrm{crystallize} \mathrm{as} \mathrm{a} \mathrm{solid} \mathrm{solution.}$ Addition of silicon to the base elements leads to a significant decrease in Gibbs energy, but, at the same time, the energy of elastic deformation increases to a level incompatible with the existence of a solid solution.

Using optimization procedure, we obtain alloys, which are superi- 
or in energy stability as compared to equiatomic ones (Table 2). They differ in composition from equiatomic HEAs. Let us consider these differences. If we consider the relationship between the base components $(\mathrm{Ni}, \mathrm{Co}, \mathrm{Fe}, \mathrm{Cr})$ in optimized alloys, the element predominance $(\mathrm{Cr}$ in system $2,3,4,5,6,7,8,12,13$ of Table 2 ; Ni in system $9,10,11,15,16,17$ of Table 2 ) is observed. Optimization of compositions leads to a significant decrease in Gibbs energy mainly due to a change in the energy of elastic distortions, enthalpy of mixing, or melting temperature.

\section{CONCLUSIONS}

1. Compositions of alloys based on $\mathrm{Ni}, \mathrm{Co}, \mathrm{Fe}, \mathrm{Cr}, \mathrm{Mn}, \mathrm{Ti}, \mathrm{V}, \mathrm{Cu}$, $\mathrm{Al}, \mathrm{Zr}$, Si elements with minimal Gibbs free energy were calculated using thermodynamic approach in approximation of regular solidsolution model.

2. The alloy compositions with minimal Gibbs free energy differ considerably from equiatomic ones.

3 . The compositions of alloys favourable for formation of singlephase solid solutions were determined.

\section{REFERENCES}

1. J. W. Yeh, S. K. Chen, S. J. Lin, J. Y. Gan, T. S. Chin, T. T. Shun et al., Adv. Eng. Mater., 6: 299 (2004); https://doi.org/10.1002/adem.200300567.

2. J. W. Yeh, JOM, 65: 1759 (2013); https://doi.org/10.1007/s11837-013-0761-6.

3. Y. Zhang, T.T. Zuo, Z. Tang et al., Progress in Materials Science, 61: 1 (2014); https://doi.org/10.1016/j.pmatsci.2013.10.001.

4. $\quad$ M. H Tsai and J. W. Yeh, Mater. Res. Lett., 2: 107 (2014); https://doi.org/10.1080/21663831.2014.912690.

5. $\quad$ D. B. Miracle and O. N. Senkov, Acta Mater., 122: 448 (2017); https://doi.org/10.1016/j.actamat.2016.08.081.

6. M. C. Gao, C. Zhang, P. Gao, F. Zhang, L. Z. Ouyang, M. Widom, and J. A. Hawk, Curr. Opin. Solid State Mater. Sci., 21: 238 (2017); https://doi.org/10.1016/j.cossms.2017.08.001.

7. Y. Tan, J. Li, S. Tang, J. Wang, and H. Kou, Journal of Alloys and Compounds, 742: 430 (2018); https://doi.org/10.1016/j.jallcom.2018.01.252.

8. F. Tian, L. K. Varga, N. Chen, L. Delczeg, and L. Vitos, Phys. Rev. B, 87: 075144 (2013); https://doi.org/10.1103/PhysRevB.87.075144.

9. F. Tian, L. Delczeg, N. Chen, L. K. Varga, J. Shen, and L. Vitos, Phys. Rev. B, 88: 085128 (2013); https://doi.org/10.1103/PhysRevB.88.085128.

10. P. Singh, A. V. Smirnov, and D. D. Johnson, Phys. Rev. B, 91: 224204 (2015); https://doi.org/10.1103/PhysRevB.91.224204.

11. D. Ma, B. Grabowski, F. Körmann, J. Neugebauer, and D. Raabe, Acta Mater., 100: 90 (2015); https://doi.org/10.1016/j.actamat.2015.08.050.

12. C. Jiang and B. P. Uberuaga, Phys. Rev. Lett., 116: 105501 (2016); 
https://doi.org/10.1103/PhysRevLett.116.105501.

13. M. C. Troparevsky, J. R. Morris, P. R. C. Kent, A. R. Lupini, G. M. Stocks, Phys. Rev. X, 5: 011041 (2015); https://doi.org/10.1103/PhysRevX.5.011041.

14. F. Zhang, C. Zhang, S. L. Chen, J. Zhu, W. S. Cao, and U. R. Kattner, CALPHAD, 5: 1 (2014); https://doi.org/10.1016/j.calphad.2013.10.006.

15. C. Zhang, F. Zhang, S. Chen, and W. Cao, JOM, 64: 839 (2012); https://doi.org/10.1007/s11837-012-0365-6.

16. O. N. Senkov, J. D. Miller, D. B. Miracle, and C. Woodward, Nature Comm., 6: 6529 (2015); https://doi.org/10.1038/ncomms7529.

17. U. Mizutani, Hume-Rothery Rules for Structurally Complex Alloy Phases (Boca Raton: CRC Press: 2010).

18. Y. Zhang, Y. J. Zhou, J. P. Lin, G. L. Chen, P. K. Liaw, Adv. Eng. Mater., 10: 534 (2008); https://doi.org/10.1002/adem.200700240.

19. Y. Zhang, Z. P. Lu, S. G. Ma, P. K. Liaw, Z. Tang, Y. Q. Cheng et al., MRS Commun., 4: 57 (2014); https://doi.org/10.1557/mrc.2014.11.

20. S. Guo, C. Ng, J. Lu, and C. T. Liu, J. Appl. Phys., 109: 103505 (2011); https://doi.org/10.1063/1.3587228.

21. S. Fang, X. Xiao, L. Xia, W. Li, and Y. Dong, J. Non-Cryst. Solids, 321: 120 (2003); https://doi.org/10.1016/S0022-3093(03)00155-8.

22. Y. F. Ye, Q. Wang, J. Lu, C. T. Liu, and Y. Yang, Scripta Mater., 104: 53 (2015); https://doi.org/10.1016/j.scriptamat.2015.03.023.

23. A. Takeuchi and A. Inoue, Sci. Eng. A, 304-306: 446 (2001); https://doi.org/10.1016/S0921-5093(00)01446-5.

24. A. B. Melnick and V. K. Soolshenko, Journal of Alloys and Compounds, 694: 223 (2017). https://doi.org/10.1016/j.jallcom.2016.09.189

25. B. Cantor, I. Chang, P. Knight, and A. Vincent, Mater. Sci. Eng. A, 375377: 213 (2004); https://doi.org/10.1016/j.msea.2003.10.257.

26. F. He, Z. Wang, Q. Wu, S. Niu, J. Li, J. Wang, and C. T. Liu, Scripta Materialia, 131: 42 (2017); https://doi.org/10.1016/j.scriptamat.2016.12.033.

27. A. Takeuchi and A. Inoue, Materials Transactions, 41: 1372 (2000); https://doi.org/10.2320/matertrans1989.41.1372.

28. A. Takeuchi and A. Inoue, Materials Transactions, 46: 2817 (2005); https://doi.org/10.2320/matertrans.46.2817.

29. WebElements Periodic Table, http://www.webelements.com/.

30. Y. Zhang, Y. J. Zhou, J. P. Lin, G. L. Chen, and P. K. Liaw, Adv. Eng. Mater., 10: 534 (2008); https://doi.org/10.1002/adem.200700240.

31. X. Yang and Y. Zhang, Mater. Chem. Phys., 132: 233 (2012); https://doi.org/10.1016/j.matchemphys.2011.11.021. 